\title{
MODEL PENGEMBANGAN PEMBELAJARAN PETANI DALAM PENGELOLAAN HUTAN RAKYAT LESTARI: Kasus Di Kabupaten Gunung Kidul, Provinsi Daerah Istimewa Yogyakarta dan Kabupaten Wonogiri, Provinsi Jawa Tengah (Model of Farmer's Learning Development in Implementing Sustainable Private Forest Management: Cases in Gunung Kidul District in Yogyakarta and Wonogiri District in Central Java)
}

\author{
Oleh/By: \\ Yumi $^{1}$, Sumardjo ${ }^{2}$, Darwis S. Gani ${ }^{3}$, Basita Ginting Sugihen ${ }^{4}$ \\ 'Pusat Pengembangan Penyuluhan Kehutanan, Badan Penyuluhan dan Pengembangan SDM Kehutanan, \\ E-mail: yumiangeliatherik@yahoo.com \\ ${ }^{2,3,4}$ Kampus IPB Bogor
}

\begin{abstract}
Forest Management is facing the challenge of implementing the sustainable forest management which includes private forest. Successfully gaining the Ecolabel Certificate, some private forest management units in Central Java and Yogyakartas districts proved that the small units run by farmers were able to implement the sustainable forest management. The farmer's success in implementing the sustainable forest management must have been gained through learning process. How the learning process and what determinant factors influencing the farmer's learning process of the sustainable private forest management were the research questions of this study. The study used explanatory survey method on 200 farmers in Gunung Kidul and Wonogiri who had succeeded in gaining the Ecolabel Certificate (HRL) and 60 farmers who had not got certification for their private forestry (NHRL) as comparison. Data collection was conducted from December 2009 to February 2010. The data were analyzed by using descriptive technique and Structural Equations Model (SEM). The conclusions are: (1) farmer's learning intensity is low. It was influenced by farmer's learning-support institutions, local institutions, extension agents competences, and farmer's individual characteristic; (2) learning-support institutions and the informal local institutions have an important role in the farmer's learning process; (3) HRL farmer's learning intensity can be improved by strengthening collaboration of the learning-support institutions and improving the extension agents competence.

Keyword: Sustainable private forest management, farmer's learning process, support system of learning-support institutions, local institutions,
\end{abstract}

\begin{abstract}
ABSTRAK
Pengelolaan hutan, termasuk pengelolan hutan oleh masyarakat menghadapi tantangan dalam mewujudkan pengelolaan hutan secara berkelanjutan (lestari). Keberhasilan petani dalam pengelolaan Hutan Rakyat di Kabupaten Gunung Kidul dan Wonogiri sampai memperoleh Sertifikat Ekolabel membuktikan bahwa masyarakat dapat mengelola hutan secara lestari. Keberhasilan tersebut merupakan hasil dari suatu proses belajar. Bagaimana pembelajaran masyarakat dan faktor penentu keberhasilan proses belajar petani tersebut merupakan pertanyaan penelitian ini. Penelitian ini menggunakan metode survey dengan 200 responden petani Hutan Rakyat sertifikasi di Kabupaten Gunung Kidul dan Wonogiri, serta 60 responden petani Hutan Rakyat yang belum disertifikasi, sebagai perbandingan. Pengambilan data dilakukan pada bulan Desember 2009 sampai dengan Februari 2010. Analisa data dilakukan menggunakan statistik deskriptif dan inferensial, Structural Equations Model
\end{abstract}


(SEM). Hasil penelitian menunjukkan bahwa: (1) Intensitas belajar petani pengelola Hutan Rakyat sertifikasi rendah, disebabkan oleh faktor kelembagaan pendukung pembelajaran, kelembagaan internal masyarakat, kompetensi penyuluh, dan karakteristik individu petani; (2) kelembagaan pendukung pembelajaran dan kelembagaan internal masyarakat memiliki peran penting dalam pembelajaran petani; (3) intensitas belajar petani dapat ditingkatkan dengan meningkatkan kolaborasi kelembagaan pendukung pembelajaran petani dan peningkatan kompetensi penyuluh.

Kata kunci: Pengelolaan hutan swasta yang berkelanjutan, proses petani belajar, sistem pendukung pembelajaran-mendukung lembaga-lembaga, institusi lokal,

\section{PENDAHULUAN}

\section{A. Latar Belakang}

Kerusakan hutan yang semakin parah, baik akibat illegal logging, kebakaran hutan dan lahan, ketimpangan antara kapasitas terpasang industri kehutanan dengan kemampuan penyediaan bahan baku kayu bulat merupakan sebagian permasalahan serius dalam pembangunan kehutanan. Di sisi lain kemiskinan penduduk yang tinggal di sekitar hutan juga merupakan masalah penting yang memerlukan perhatian khusus dalam pembangunan kehutanan. Hutan rakyat merupakan salah satu alternatif penting untuk menjawab permasalahan tersebut. Hutan rakyat telah terbukti berperan dalam rehabilitasi hutan dan lahan, menyediakan stok kayu bulat dan menjadi tabungan bagi keluarga di sekitar hutan. Darusman (1995) menegaskan bahwa hutan rakyat dan industri pengolahan hasilnya merupakan pilihan teknologi budidaya dan industri yang tepat guna bagi wilayah-wilayah berlahan marjinal dengan kondisi sosio budaya tradisional.

Tantangan yang dihadapi dalam pengembangan hutan rakyat ialah berkaitan dengan adanya issue global warming dan ekolabel, yang mensyaratkan kayu-kayu bersertifikat sebagai ketentuan untuk dapat masuk pasar kayu internasional. Unit manajemen pengelolaan hutan rakyat di Kabupaten Gunung Kidul (Gunung Kidul) dan Kabupaten Wonogiri (Wonogiri), yang dikelola oleh masyarakat setempat telah membuktikan bahwa rakyat telah mampu mengelola hutan secara lestari dan mendapatkan sertifikat Ekolabel.

Keberhasilan masyarakat tersebut melalui suatu proses belajar, dan proses belajar masyarakat pada dasarnya merupakan kegiatan penyuluhan. Perubahan perilaku masyarakat ke arah kemandirian dalam pengelolaan hutan merupakan salah satu tujuan penyuluhan kehutanan. Penyuluhan kehutanan terus berupaya mengembangkan paradigma penyuluhan ke arah pemberdayaan masyarakat. Namun, sampai dengan saat ini belum ada acuan penyuluhan kehutanan yang jelas bagaimana memfasilitasi proses belajar masyarakat yang baik, yang mengarah pada pemberdayaan masyarakat. Program-program penyuluhan kehutanan sampai dengan saat ini masih lebih banyak bersifat kegiatan "charity" yang tidak memberdayakan masyarakat. Faktor-faktor yang mempengaruhi keberhasilan proses belajar petani dan bagaimana mengembangkan pembelajaran petani tersebut, merupakan permasalahan yang ingin diperoleh jawabannya dalam penelitian ini.

\section{B. Tujuan Penelitian}

(1) Menganalisis faktor penentu intensitas belajar petani dalam pengelolaan hutan rakyat lestari; (2) Menganalisis kelembagaan yang berperanan penting dalam pembelajaran petani

Model Pengembangan Pembelajaran Petani dalam Pengelolaan Hutan Rakyat Lestari: ...... (Yumi et al.) 
dalam pengelolaan hutan rakyat lestari; (3) Merumuskan konsep model pengembangan pembelajaran petani dalam pengelolaan hutan rakyat lestari.

\section{METODE PENELITIAN}

\section{A. Kerangka Berpikir}

Pengelolaan hutan rakyat secara lestari merupakan salah satu peluang baik bagi pembangunan kehutanan berkelanjutan. Banyak pengalaman telah membuktikan bahwa untuk pembangunan kehutanan berkelanjutan tidak dapat dicapai dengan pendekatan to $p$ down, dengan penekanan pada transfer pengetahuan dan teknologi. Pendekatan top down, dengan transfer pengetahuan dan teknologi tidak dapat menghasilkan masyarakat yang mandiri dalam mendukung, berpartisipasi dan bahkan mengelola hutannya secara lestari. Campbell (1997), yang diacu dalam Suhardjito (2000) mengungkapkan perlunya perubahan konseptual pembangunan kehutanan, yang lebih banyak memberikan peluang kepada partisipasi masyarakat. Sejalan dengan hal tersebut Chambers (1993) menegaskan perlunya perubahan dari pendekatan cetak biru ke arah proses belajar.

Mengacu pada pemikiran Campbell dan Chambers tersebut, maka untuk pembangunan kehutanan berkelanjutan atau lestari, termasuk pengelolaan hutan rakyat berkelanjutan membutuhkan perubahan paradigma pengelolaan hutan rakyat dari pendekatan top down ke arah pendekatan pembelajaran (Tabel1).

Tabel 1. Perubahan paradigma pengelolaan hutan rakyat dari pendekatan top down ke arah pendekatan pembelajaran

Table 1. Paradigm change of private forests management from top down to learning approach)

\begin{tabular}{|l|l|l|l|}
\hline No & \multicolumn{1}{|c|}{$\begin{array}{c}\text { Aspek } \\
(\text { Aspect })\end{array}$} & \multicolumn{1}{|c|}{$\begin{array}{c}\text { Pendekatan top down } \\
\text { (Top down approach) }\end{array}$} & \multicolumn{1}{|c|}{$\begin{array}{c}\text { Pendekatan pembelajaran } \\
\text { (Learning approach) }\end{array}$} \\
\hline 1. & Tujuan & $\begin{array}{l}\text { Peningkatan ketrampilan, } \\
\text { pencapain target produktivitas }\end{array}$ & $\begin{array}{l}\text { Peningkatan kapasitas, } \\
\text { pemberdayaan masyarakat }\end{array}$ \\
\hline 2. & $\begin{array}{l}\text { Fokus dan } \\
\text { orientasi }\end{array}$ & $\begin{array}{l}\text { Output pencapaian target dan } \\
\text { kondisi fisik hutan }\end{array}$ & $\begin{array}{l}\text { Proses belajar, keberadaan } \\
\text { masyarakat pengelola hutan rakyat } \\
\text { dan kondisi fisik hutan }\end{array}$ \\
\hline 3. & Diawali & $\begin{array}{l}\text { Perencanaan program oleh } \\
\text { pemerintah atau lembaga } \\
\text { eksternal lainnya }\end{array}$ & $\begin{array}{l}\text { Kesadaran kritis masyarakat, dan } \\
\text { perencanaan bersama }\end{array}$ \\
\hline 4. & Materi & $\begin{array}{l}\text { Seragam, ditentukan penyusun } \\
\text { kebijakan, lembaga eksternal }\end{array}$ & $\begin{array}{l}\text { Bervariasi, sesuai kebutuhan dan } \\
\text { permasalahan, lokal spesifik }\end{array}$ \\
\hline 5. & Metode & $\begin{array}{l}\text { Ceramah, diskusi tapi masih } \\
\text { didominasi pihak atau orang } \\
\text { tertentu }\end{array}$ & $\begin{array}{l}\text { Sharing pengalaman (Experiental } \\
\text { learning), belajar mandiri, learning by } \\
\text { doing, discovery learning }\end{array}$ \\
\hline 6. & Komunikasi & Satu arah & Konvergen, banyak arah \\
\hline 7. & Peran Penyuluh & Guru & $\begin{array}{l}\text { Fasilitator, Motivator, Dinamisator, } \\
\text { Kompetensi peningkatan kapasitas } \\
\text { petani, kompetensi sosial, } \\
\text { kompetensi manajemen kelompok } \\
\text { /kelembagaan, kompetensi teknis }\end{array}$ \\
\hline 8. & $\begin{array}{l}\text { Kompetensi } \\
\text { penyuluh }\end{array}$ & Kompetensi teknis & $\begin{array}{l}\text { Menguatkan lembaga internal } \\
\text { masyarakat yang sudah ada dan } \\
\text { mengakar dalam masyarakat }\end{array}$ \\
\hline 9. & $\begin{array}{l}\text { Kelembagaan } \\
\text { masyarakat }\end{array}$ & $\begin{array}{l}\text { Dibentuk sesuai kepentingan } \\
\text { pemerintah atau lembaga } \\
\text { eksternal lainnya }\end{array}$ & \\
\hline
\end{tabular}


Tabel 1. Lanjutan

Table 1. Continued

\begin{tabular}{|c|l|l|l|}
\hline No & \multicolumn{1}{|c|}{$\begin{array}{c}\text { Aspek } \\
\text { (Aspect) }\end{array}$} & \multicolumn{1}{|c|}{$\begin{array}{c}\text { Pendekatan top down } \\
(\text { Top down approach) }\end{array}$} & $\begin{array}{c}\text { Pendekatan pembelajaran } \\
\text { (Learning approach) }\end{array}$ \\
\hline 10. & Kepemimpinan & $\begin{array}{l}\text { Otoriter, peran pemimpin formal } \\
\text { lebih menonjol }\end{array}$ & $\begin{array}{l}\text { Demokratis, banyak memberikan } \\
\text { peran pada pemimpin informal, } \\
\text { tokoh masyarakat }\end{array}$ \\
\hline 11. & $\begin{array}{l}\text { Kelembagaan } \\
\text { pendukung } \\
\text { (ekternal) }\end{array}$ & $\begin{array}{l}\text { Bekerja sesuai dengan visi, misi } \\
\text { dan tujuan masing-masing }\end{array}$ & Kolaboratif dan sistemik \\
\hline 12. & $\begin{array}{l}\text { Perilaku } \\
\text { masyarakat }\end{array}$ & $\begin{array}{l}\text { Pesimis, selalu bergantung pada } \\
\text { inisiatif dan bantuan pihak luar }\end{array}$ & $\begin{array}{l}\text { Optimis, mandiri, mampu bekerja } \\
\text { sama, selalu berinisiatif untuk } \\
\text { mengembangkan hutan rakyat lestari }\end{array}$ \\
\hline
\end{tabular}

Keberhasilan petani pengelola hutan rakyat memperoleh sertifikat ekolabel di Kab. Gunung Kidul dan Kab. Wonogiri merupakan hasil dari proses belajar masyarakat yang intensif dalam mengelola hutan secara lestari. Hasil dari intensitas belajar tersebut terwujud pada perilaku masyarakat dalam mengelola hutan rakyat secara lestari. Intensitas belajar masyarakat dalam pengelolaan hutan rakyat lestari dipengaruhi oleh banyak faktor. Berdasarkan pendapat Klausmeier dan Goodwin (1971), Seng et al. (2001), Sudjana (2000), Suryabrata (2006), Soemanto (2006), secara garis besar intensitas belajar masyarakat dipengaruhi oleh faktor eksternal dan internal. Faktor internal yang mempengaruhi intensitas belajar dalam penelitian ini adalah karakteristik petani sebagai peserta belajar. Faktor eksternal yang mempengaruhi intensitas belajar dalam penelitian ini dibatasi 4 variabel yaitu : Kompetensi penyuluh/pendamping; Pendekatan pembelajaran; Kelembagaan masyarakat; dan Kelembagaan pendukung pembelajaran (Gambar 1).

\section{B. Metode}

Desain penelitian adalah survey dan bersifat penjelasan (Explanatory Survey) yaitu menjelaskan hubungan kausalitas antara peubah-peubah penelitian. Lokasi penelitian ditentukan secara purposive yaitu lokasi yang terdapat unit pengelolaan hutan rakyat lestari (HRL) yang telah disertifikasi. Populasi adalah petani pengelola HRL di Kab.Gunung Kidul dan Kab.Wonogiri. Pengambilan sampel dilakukan dengan metode stratified random sampling dengan strata tingkat keaktifan dalam kelompok (pengurus dan bukan pengurus). Di masingmasing kabupaten dipilih juga satu kelompok pengelolaan hutan rakyat yang belum disertifikasi (NHRL) pada satu desa sebagai pembanding. Jumlah keseluruhan responden dalam penelitian ini adalah 200 orang petani HRL dan 60 orang petani NHRL sebagai pembanding.

Pengumpulan data dilakukan pada bulan Desember 2009 sampai Februari 2010. Pengumpulan data primer menggunakan wawancaran terstruktur dengan menggunakan kuesioner, wawancara mendalam dan observasi lapangan. Pengolahan dan analisa data dilakukan dengan menggunakan statistik deskriptif dan statistik inferensial. Statistik deskriptif menggunakan program SPSS 16.0 sedangkan statistik inferensial menggunakan analisa Structural Equation Model (SEM) program LISREL 8.70.

Model Pengembangan Pembelajaran Petani dalam Pengelolaan Hutan Rakyat Lestari: ...... (Yumi et al.) 


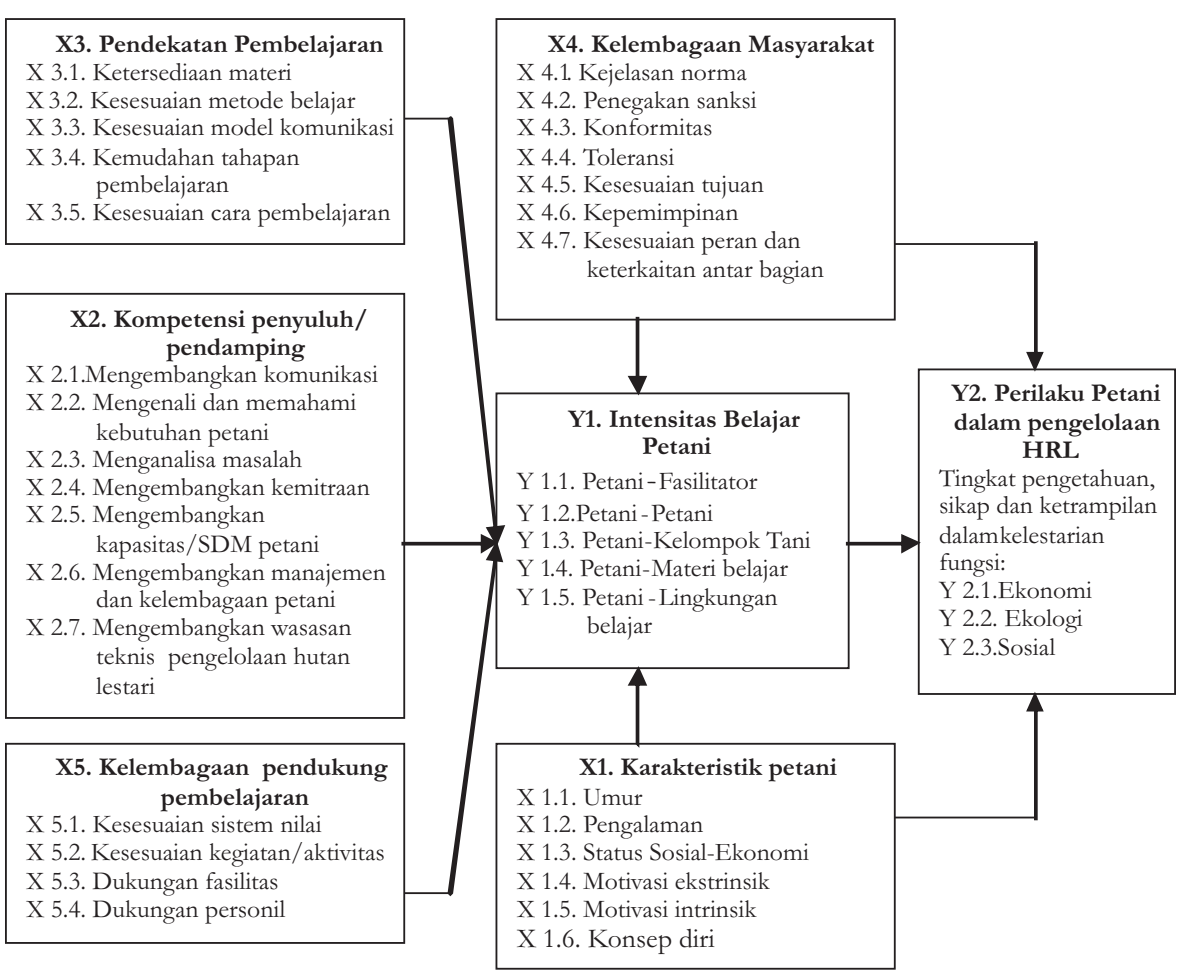

Gambar 1. Kerangka berpikir pengembangan pembelajaran petani dalam pengelolaan HRL

Figure 1. Framework of farmer's learning development in implementing sustainable private forest management

\section{HASIL DAN PEMBAHASAN}

\section{A. Faktor-Faktor yang Mempengaruhi Intensitas Belajar Petani}

Intensitas belajar petani Hutan Rakyat Lestari secara keseluruhan di kedua lokasi rendah, yaitu berada pada skor rataan 37,8-61,0. Tetapi bila dilihat skor rataan antar lokasi, terdapat perbedaan nyata antara intensitas belajar petani hutan rakyat sertifikasi di Gunung Kidul dan Wonogiri. Semua indikator intensitas belajar di Gunung Kidul tergolong sedang (skor rataan 49,4-64,9), sedangkan di Wonogiri tergolong rendah (skor rataan 24,2-57,0). Bila dibandingkan dengan petani non sertifikasi (NHRL) di kedua lokasi, ternyata nilai intensitas belajar petani NHRL lebih rendah, yaitu berada pada nilai skor rataan 5,6-31,2. Interaksi petani dengan petani di kedua lokasi paling tinggi, di Gunung Kidul skor rataan 64,9 dan di Wonogiri skor rataan 57. Hal ini mengindikasikan petani sertifikasi, baik di Gunung Kidul maupun Wonogiri masih lebih banyak memanfaatkan pembelajaran melalui sesama petani. Sedangkan interaksi petani dengan materi belajar paling rendah, hal ini berkaitan dengan rendahnya petani memanfaatkan sumber-sumber materi pembelajaran di luar apa yang didapatkan dari penyuluh melalui pertemuan kelompok. 
Hasil analisa SEM menunjukkan faktor-faktor yang secara nyata mempengaruhi intensitas belajar petani dari urutan yang paling besar pengaruhnya yaitu: Kelembagaan pendukung pembelajaran petani (X5), Kelembagaan masyarakat (X4), Karakteristik petani (X1), dan Kompetensi Penyuluh dan Pendamping (X2). Faktor Pendekatan pembelajaran (X3) dalam penelitian ini tidak berpengaruh nyata terhadap intensitas belajar petani. Persamaan struktural faktor-faktor yang mempengaruhi intensitas belajar petani dalam pengelolaan HRL adalah: $\mathrm{Y} 1=0,26 * \mathrm{X} 1+0,17 * \mathrm{X} 2+0,26 * \mathrm{X} 4+0,31 * \mathrm{X} 5 ; \mathrm{R}^{2}=0,78$.

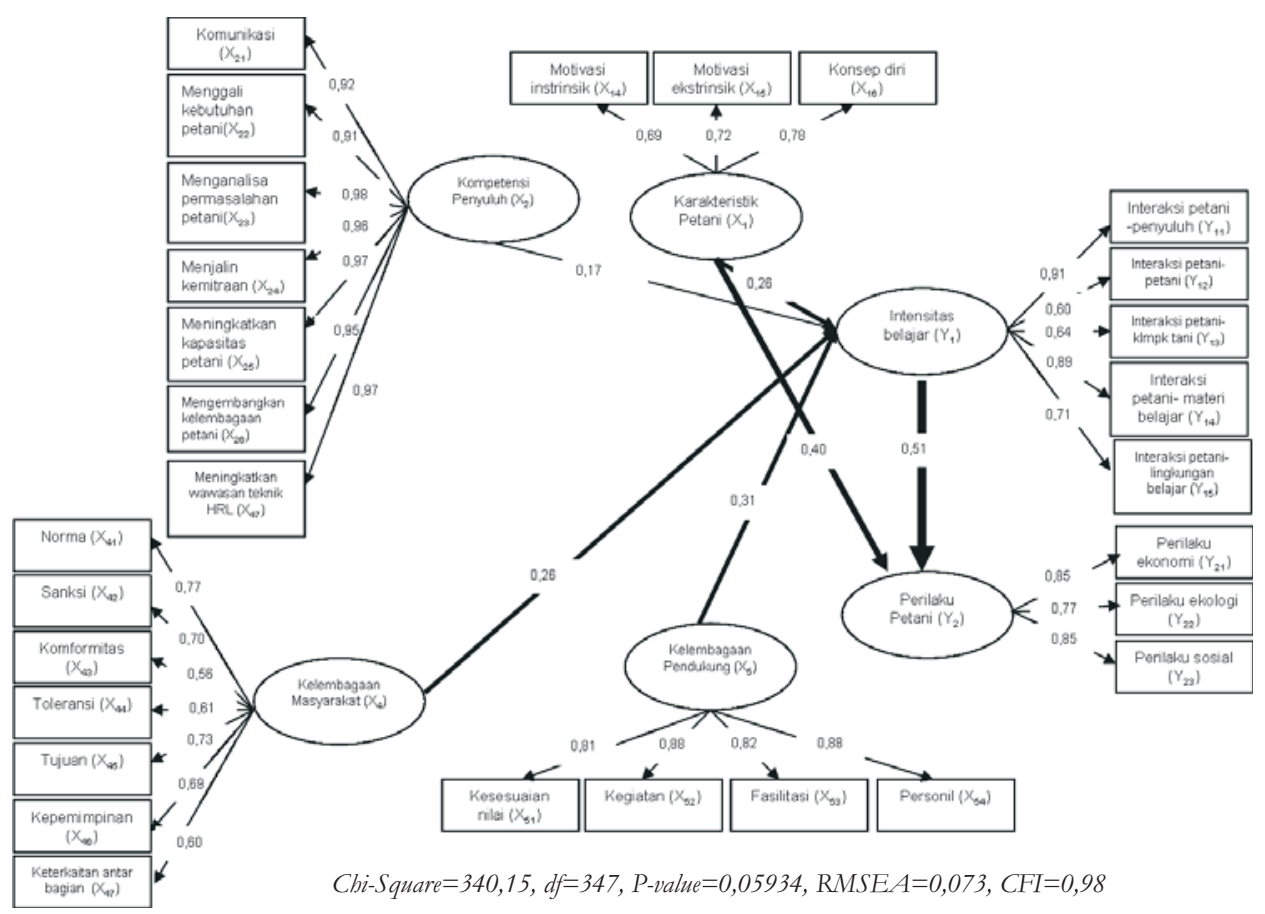

Gambar 2. Model struktural pengembangan pembelajaran petani hutan rakyat lestari

Figure 2. Structural model of farmer's learning development in implementing sustainable private forest management

Kelembagaan pendukung pembelajaran petani HRL paling kuat mempengaruhi intensitas belajar petani di Gunung Kidul dan Wonogiri. Lembaga pendukung pembelajaran pengelolaan Hutan Rakyat Lestari di Gunung Kidul yang dinilai berperan dalam pembelajaran petani ialah Pusat Kajian Hutan Rakyat (PKHR) - Universitas Gadjah Mada (UGM), Dinas Kehutanan dan Perkebunan Kab. Gunung Kidul, LSM Shorea, dan LSM Arupa. Lembaga pendukung pembelajaran Hutan Rakyat Lestari di Wonogiri ialah Dinas Kehutanan dan Perkebunan (Dishutbun) Kab. Wonogiri serta PERSEPSI.

Terdapat perbedaan nyata antara skor rataan Kelembagaan pendukung Pembelajaran HRL dan NHRL. Skor rataan untuk kelembagaan pendukung pembelajaran HRL berada pada kisaran nilai 48,1-53,4 sedangkan NHRL berada pada kisaran 9,5-36,9. Demikian juga terdapat perbedaan nyata antara kelembagaan pendukung pembelajaran HRL di Gunung

Model Pengembangan Pembelajaran Petani dalam Pengelolaan Hutan Rakyat Lestari: ...... (Yumi et al.) 
Kidul dan Wonogiri. Kelembagaan pendukung pembelajaran di Gunung Kidul tergolong sedang dengan skor rataan 63,4-72,4 sedangkan di Wonogori tergolong rendah dengan skor rataan $34,2-37,3$.

Perbedaan mendasar yang membedakan pembelajaran Hutan Rakyat Lestari di Gunung Kidul dan Wonogiri adalah sinergitas kelembagaan pendukung pembelajaran petani.Pembelajaran Hutan Rakyat Lestari di Gunung Kidul direncanakan, dilaksanakan, dipantau dan dievaluasi secara terpadu oleh suatu Kelompok Kerja (POKJA) Hutan Rakyat Lestari, yang ditetapkan berdasarkan Keputusan Bupati Kabupaten Gunung Kidul tanggal 20 September 2005. Pokja HRL tersebut, terdiri dari berbagai kalangan, baik pemerintah daerah, Perguruan Tinggi, LSM/organisasi non politik dan masyarakat petani. Adanya perbedaan keberadaan kelembagaan pendukung pembelajaran petani di Gunung Kidul dan Wonogiri menyebabkan adanya perbedaan intensitas belajar petani. Aspek kelembagaan pendukung yang berpotensi mempengaruhi intensitas belajar petani adalah dukungan kegiatan dan dukungan personil.

Aspek kelembagaaan masyarakat yang berpotensi mempengaruhi intensitas belajar petani adalah norma (nilai, aturan), kesesuaian tujuan, dan kepemimpinan. Norma, nilai-nilai, aturan dalam masyarakat yang mendukung intensitas belajar petani HRL ialah kepercayaan kepada pemimpin/pemerintah, aturan tentang kewajiban melakukan penanaman setelah penebangan, gotong royong atau sambatan, dan nilai hidup atau budaya kerja keras. Kesesuaian tujuan organisasi kemasyarakatan dengan tujuan anggota, mempengaruhi intensitas belajar petani. Kesesuaian tujuan ini penting bagi kelangsungan organisasi dan partisipasi anggota. Sebagai contoh: proses sertifikasi mensyarakatkan adanya organisasi formal, yang dibentuk bukan atas kesadaran, kemauan dan tujuan masyarakat, seperti Forum Komunitas Petani Sertifikasi (FKPS) di Wonogiri, sehingga akhirnya tidak berjalan, sebaliknya arisan menjadi kelembagaan masyarakat yang dinilai baik mendukung pembelajaran HRL. Kepemimpinan berpotensi mempengaruhi intensitas belajar petani. Sebagian besar ketua kelompok HRL adalah kepala dusun, yang menjadi panutan masyarakat. Segi positif ketua kelompok yang merangkap kepala dusun ialah dinamika kelompok cukup terjaga, luasnya jaringan informasi maupun anggaran yang dapat diakses oleh ketua memberi dampak positif kepada kelompok tani dan dusun yang dipimpinnya. Hal ini sejalan dengan pendapat Djogo (2005) bahwa kepemimpinan menjadi andalan dalam upaya pembangunan berkelanjutan.

Karakteristik petani hutan rakyat mempengaruhi intensitas belajarnya. Karakteristik petani hutan rakyat yang telah disertifikasi dan non sertifikasi berbeda nyata dalam semua indikatornya kecuali tingkat sosial ekonomi. Perbedaan rataan umur dan pengalaman antara petani sertifikasi dan non sertifikasi tidak terpaut terlalu jauh (rataan umur petani HRL 51, dan NHRL 47 serta rataan pengalaman HRL 25 tahun dan NHRL 18 tahun). Perbedaan yang sangat menyolok antara karakteristik petani hutan rakyat sertifikasi dan non sertifikasi adalah pada motivasi ekstrinsik dan konsep diri. Motivasi ekstrinsik dan konsep diri petani hutan rakyat sertifikasi termasuk dalam kategori tinggi dan positif (80 dan 76), sedangkan motivasi ekstrinsik dan konsep diri petani non sertifikasi adalah rendah (30) dan negatif (14).

Aspek karakteristik petani yang berpotensi mempengaruhi intensitas belajar ialah aspek konsep diri petani, motivasi ekstrinsik dan motivasi intrinsik. Konsep diri yang positif sangat berpengaruh terhadap proses belajar seseorang. Konsep diri dapat dibentuk dari pengalaman seseorang. Konsep diri terhadap HRL di Gunung Kidul positif, sehingga berpengaruh terhadap intensitas belajar di Gunung Kidul yang tergolong sedang. Motivasi ekstrinsik sangat berkaitan dengan dukungan dari kelembagaan pendukung pembelajaran 
petani HRL. Petani HRL di Gunung Kidul memiliki motivasi ekstrinsik yang lebih tinggi dibandingkan dengan petani HRL di Wonogiri, karena keberadaan kelembagaan pendukung pembelajaran HRL dan kegiatan yang berkelanjutan. Motivasi intrinsik petani di kedua lokasi dalam pembelajaran HRL adalah tinggi (skor rataan 88 dan 84). Untuk masyarakat di kedua lokasi ternyata mengembangkan hutan rakyat, yang secara sederhana dilaksanakan dengan menanam pohon, sudah dilakukan dengan kesadaran tinggi, bahkan sudah membudaya.

Kompetensi penyuluh dan pendamping juga mempengaruhi intensitas belajar petani. Kompetensi Penyuluh Kehutanan dan pendamping dalam proses pembelajaran sertifikasi Hutan Rakyat Lestari, di kedua lokasi penelitian baik sertifikasi maupun non sertifikasi berbeda nyata, walaupun nilai skor rataannya berada pada kategori yang sama, yaitu "rendah". Terdapat perbedaan yang nyata pada penilaian petani sertifikasi terhadap kompetensi penyuluh kehutanan maupun pendamping antara kedua lokasi penelitian. Petani sertifikasi di Gunung Kidul menilai kompetensi penyuluh kehutanan maupun pendamping dalam pembelajaran Hutan Rakyat Lestari "sedang" (skor rataan 61,1-64,7). Sedangkan petani sertifikasi di Wonogiri, menilai kompetensi penyuluh dan pendamping "rendah" (19,1-27), bahkan petani NHRL di kedua lokasi penelitian menilai"sangat rendah" (8,3-29,4).

Aspek kompetensi penyuluh dan pendamping yang berpotensi mempengaruhi intensitas belajar petani adalah kemampuan penyuluh dalam : menganalisa permasalahan, meningkatkan kapasitas petani dan mengembangkan wawasan teknis petani. Kemampuan menganalisa permasalahan petani merupakan aspek yang dikehendaki responden untuk dimiliki oleh penyuluh dan pendamping. Kenyataan yang ada intensitas pertemuan petani dengan penyuluh yang sangat rendah, penyuluh dan pendamping yang tidak tinggal bersama dengan petani di desa menyebabkan adanya keterbatasan pendamping dan penyuluh dalam melihat permasalahan dari sudut pandang petani. Di sisi lain, pendamping dan penyuluh memiliki target-target yang ditetapkan oleh institusi tempat mereka bekerja, khususnya pendampingan dalam proses sertifikasi ekolabel, sehingga fokus perhatian lebih kepada pencapaian target-target yang ditetapkan oleh institusi kerja mereka, dan bukan kepada kebutuhan dan permasalahan riil yang dihadapi petani khususnya berkaitan dengan pengelolaan HRL. Peningkatan kapasitas petani, khususnya di Gunung Kidul, selain berkaitan dengan pengelolaan atau manajemen usaha maupun kelompok, juga berkaitan dengan kemampuan teknis pengelolaan HRL, termasuk penanganan pasca panen. Peningkatan kapasitas petani memerlukan frekuensi dan interaksi yang lebih banyak, baik dengan penyuluh, materi belajar maupun lingkungan belajar. Peningkatan wawasan teknis petani: Pengetahuan teknis pengelolaan HRL yang baru, yang dikombinasikan dengan pengetahuan lokal masyarakat, sesuai dengan kebutuhan, mudah dipahami dan diterapkan oleh petani HRL menjadi hal-hal menarik yang dapat meningkatkan intensitas belajar petani. Hal ini sejalan dengan pendapat Chamala dan Shingi (1997) bahwa penyuluh harus memiliki kompetensi dalam menjalankan empat peranan penting yaitu pemberdayaan, pengelolaan kelompok dan penguatan kelembagaan masyarakat, pengembangan sumberdaya petani, serta pemecahan masalah dan pendidikan.

Pendekatan pembelajaran tidak berpengaruh nyata terhadap intensitas belajar petani. Pendekatan pembelajaran yang digunakan penyuluh dan pendamping kepada petani HRL dan NHRL di kedua kabupaten dinilai berbeda. Walaupun penilaian terhadap pendekatan pembelajaran oleh petani hutan rakyat sertifikasi dan non sertifikasi di kedua kabupaten termasuk pada kategori yang sama, yaitu kategori "rendah" tetapi memiliki rentang skor rataan yang cukup jauh. Skor rataan pendekatan belajar yang dinilai petani HRL berada pada kisaran 42,6-48,2 sedangkan pada petani NHRL berada pada kisaran 4,4-7,7. Perbedaan yang

Model Pengembangan Pembelajaran Petani dalam Pengelolaan Hutan Rakyat Lestari: ...... (Yumi et al.) 
cukup menyolok ini dapat dimengerti mengingat petani hutan rakyat sertifikasi di kedua lokasi penelitian sudah mendapatkan pendampingan dan pembelajaran Hutan Rakyat Lestari dari penyuluh dan pendamping. Sedangkan untuk petani hutan rakyat non sertifikasi di Gunung Kidul dan Wonogiri belum pernah mendapatkan pendampingan atau pembelajaran Hutan Rakyat Lestari. Walaupun pembelajaran HRL yang diperoleh dari penyuluh dan pendamping di Wonogiri juga tergolong masih rendah (skor rataan 26,4-31,4) dibandingkan di Gunung Kidul (skor rataan 58,7-65,6).

Hasil penelitian mengungkapkan bahwa keberhasilan petani HRL di kedua lokasi dalam memperoleh sertifikasi Ekolabel bukan semata-mata hasil dari pembelajaran selama proses pendampingan. Pembelajaran petani tentang hutan rakyat selama ini telah berlangsung lama, jauh sebelum proses pendampingan sertifikasi dan pembelajaran petani HRL lebih banyak diwariskan turun menurun dari orang tua mereka.

Pendekatan pembelajaran yang digunakan dalam pendampingan pengelolaan hutan rakyat lestari di kedua lokasi lebih cenderung menggunakan pendekatan mengajar (teaching) daripada pembelajaran (learning) dan masih belum menerapkan empat prinsip pembelajaran orang dewasa yang diperkenalkan oleh Knowles (1979) yaitu: (1) Orang dewasa memiliki konsep diri sehingga mampu mengambil keputusan sendiri,memikul tanggung jawab dan menyadari tugas dan perannya. Oleh karenanya perlu diciptakan iklim belajar yang sesuai keadaan orang dewasa dengan melibatkan peserta belajar dalam mengidentifikasi kebutuhan belajar, perencanaan belajar, proses belajar mengajar dan mengevaluasi kemajuan dalam proses belajarnya; (2) orang dewasa memiliki banyak pengalaman, yang membentuk pendapat dan kepribadian orang tersebut. Sehingga dalam pembelajaran perlu dimanfaatkan dan menggali kekayaan pengalaman yang dimiliki orang dewasa, proses belajar ditekankan pada aplikasi praktis dan belajar dari pengalamannya; (3) orang dewasa memiliki kesiapan belajar, berdasarkan kebutuhan yang dirasakan; dan (4) orientasi belajar orang dewasa adalah aplikasi belajar langsung dimanfaatkan sehingga materi pembelajaran berorientasi pada pemecahan masalah dan pengalaman belajar dirancang berdasarkan masalah atau fokus perhatian peserta belajar.

\section{Faktor-Faktor yang Mempengaruhi Perilaku Petani}

Perilaku petani hutan rakyat sertifikasi (HRL) dalam mengelola hutan berbeda nyata dengan petani hutan rakyat non sertifikasi (NHRL) di kedua lokasi penelitian. Perilaku petani sertifikasi tergolong sedang (skor rataan 59,9-75,5), sedangkan perilaku petani non sertifikasi tergolong rendah $(39,6-50,5)$. Bila dikaji mendalam ternyata terdapat perbedaan juga antara perilaku kelola hutan petani sertifikasi maupun perilaku petani non sertifikasi di Gunung Kidul dan Wonogiri. Pada petani sertifikasi, aspek produksi dan ekologi di Gunung Kidul dan Wonogiri masuk dalam kategori yang sama, yaitu "sedang". Tetapi pada aspek sosial, perilaku petani Gunung Kidul tergolong "tinggi” (skor rataan 80,1) sedangkan di Wonogiri termasuk "sedang" (skor rataan 71). Perilaku petani non sertifikasi di Gunung Kidul tergolong "sedang" pada aspek sosial dan ekologi, sedangkan di Wonogiri tergolong "rendah" pada semua aspeknya.

Meskipun perilaku petani dalam pengelolaan hutan rakyat belum mengacu pada aspek-aspek manajemen hutan, tetapi perilaku petani hutan rakyat dalam menjaga kelestarian sudah terbukti dan sangat mendukung nilai ekonomi, ekologi dan sosial. Konsep kelestarian yang dikembangkan oleh petani hutan rakyat sangat sederhana, yaitu adanya kewajiban penanaman kembali setelah dilakukan penebangan pohon, selain itu penanaman dilakukan 
kapan saja meskipun tidak dilakukan penebangan. Adanya kearifan lokal petani hutan rakyat tersebut di atas, dan juga adanya konsep "tebang butuh" menyelamatkan kondisi hutan rakyat di Gunung Kidul dan Wonogiri. Petani hutan rakyat betul-betul menyadari apa yang akan terjadi jika mereka menebang terlalu banyak.

Perilaku petani dalam mengelola HRL (Y2) dipengaruhi secara nyata oleh faktor : Intensitas Belajar (Y1) dan Karakteristik petani (X1), yang dituliskan dengan persamaan struktural : $\mathrm{Y} 2=0,51 * \mathrm{Y} 1+0,40 * \mathrm{X} 1 ; \mathrm{R}^{2}=0,72$. Hasil SEM menunjukkan bahwa variabel kelembagaan masyarakat (X4) berpengaruh tidak nyata terhadap perilaku petani. Intensitas belajar petani HRL di kedua lokasi tergolong rendah, dan aspek intensitas belajar petani yang berpotensi mempengaruhi perilaku petani adalah: interaksi petani dengan penyuluh, materi pembelajaran, dan lingkungan belajar. Interaksi petani dengan penyuluh/pendamping sangat jarang, tetapi petani HRL khususnya di Gunung Kidul mendapatkan pembelajaran HRL dari pertemuan tersebut, walaupun masih terbatas di kalangan pengurus. Interaksi petani dengan materi belajar, khususnya di Wonogiri sangat rendah karena petani hanya mengandalkan pembelajaran dari pertemuan dengan penyuluh, yang sangat jarang terjadi. Interaksi dengan materi belajar, khususnya di Gunung Kidul dinilai bermanfaat dalam membentuk perilaku positif dalam HRL. Interaksi petani dengan lingkungan belajar dapat meningkatkan perilaku positif petani dalam pengelolaan HRL. Walaupun intensitas belajar petani HRL tergolong rendah, tetapi secara bersama-sama dengan karakteristik petani berpengaruh secara nyata terhadap perilaku petani HRL.

Aspek karakteristik petani, khususnya aspek konsep diri, motivasi ekstrinsik dan motivasi intrinsik mempengaruhi perilaku petani dalam mengelola HRL. Konsep diri yang positif menghasilkan perilaku yang baik dalam pengelolaan Hutan Rakyat Lestari, demikian sebaliknya konsep diri yang negatif menghasilkan perilaku yang kurang baik dalam pengelolaan Hutan Rakyat Lestari. Hal ini terungkap dari hasil penelitian, yang menunjukkan bahwa petani di Wonogiri walaupun mempunyai motivasi intrinsik yang tinggi, tetapi karena adanya konflik internal, kecemburuan sosial, ketidakpercayaan terhadap LSM pendamping, kurangnya pembinaan dan tidak berlanjutnya pendampingan telah menurunkan semangat petani bahkan menghasilkan konsep diri yang negatif terhadap perkembangan Hutan Rakyat Lestari. Motivasiekstrinsik yang kurang baik, akan berdampak negatif terhadap perilaku petani, sekalipun motivasi intrinsiknya baik. Hal ini terbukti di Wonogiri, dimana motivasi intrinsik petani tinggi, namun kurang didukung atau difasilitasi oleh kelembagaan pendukung pembelajaran dan lingkungan belajar yang baik sehingga menimbulkan motivasi ekstrinsik yang kurang baik. Motivasi intrinsik petani hutan rakyat sertifikasi di kedua lokasi penelitian yang sangat tinggi, yang dibentuk melalui pengalaman, telah mempengaruhi pengetahuan, sikap dan keterampilan mereka dalam pengelolaan Hutan Rakyat Lestari. Petani sertifikasi, baik di Gunung Kidul dan Wonogiri lebih banyak mendapatkan pengetahuan melalui pembelajaran sendiri dan turun temurun dari orang tua mereka. Pengetahuan yang diperoleh melalui pengalaman dan pembelajaran sendiri ini, telah membentuk kesadaran mereka tentang pentingnya Hutan Rakyat Lestari. Dengan demikian kesadaran yang kemudian memotivasi mereka untuk lebih banyak belajar dan mengembangkan Hutan Rakyat Lestari.

\section{Kelembagaan yang Berperan Penting dalam Pembelajaran Petani HRL}

Kelembagaan yang berperan penting dalam pembelajaran petani HRL dalam penelitian ini ialah kelembagaan pendukung pembelajaran petani dan kelembagaan masyarakat. Kelembagaan pendukung pembelajaran petani yang terintegrasi dan

Model Pengembangan Pembelajaran Petani dalam Pengelolaan Hutan Rakyat Lestari: ...... (Yumi et al.) 
berkolaborasi dengan baik menghasilkan intensitas belajar petani HRL yang lebih baik. Salah satu kelemahan Pokja HRL di Gunung Kidul ialah belum melibatkan lembaga pemasaran dan perkreditan. Saat ini pemasaran kayu HRL dan kredit menjadi salah satu kendala dalam pengembangan HRL. Dukungan kegiatan yang dapat mengakomodir kebutuhan, nilai-nilai dan minat masyarakat serta berkelanjutan, dan dukungan personil yang kompeten dalam pendampingan masyarakat berdampak positif terhadap pembelajaran petani. Hal ini sejalan dengan hasil penelitian Narayan (1993) diacu dalam Pretty (1995) bahwa kesuksesan kelembagaan eksternal ditentukan oleh sejauhmana kelembagaan eksternal mengakomodir orientasi utama atau nilai-nilai, kebutuhan dan minat masyarakat lokal.

Kelembagaan masyarakat, baik dari sisi aturan maupun organisasi berperan penting dalam pembelajaran petani HRL. Adanya aturan mengenai penebangan dan penanaman kembali yang diwariskan turun temurun, kepercayaan terhadap pemimpin, budaya gotong royong dan bekerja keras, lembaga informal dalam masyarakat seperti: arisan, yasinan, kelompok tani sangat berperan dalam pembelajaran petani HRL. Aturan dan organisasi formal yang menjadi persyaratan dalam proses sertifikasi (seperti pembentukan FKPS, koperasi) belum sepenuhnya dapat diterima dan dijalankan dengan baik oleh petani HRL, karena petani belum sepenuhnya menyadari peranan dan merasakan manfaat keberadaan organisasi tersebut.

\section{E. Model dan Strategi Pengembangan Pembelajaran Petani HRL}

Dengan memperhatikan faktor-faktor yang mempengaruhi pembelajaran petani HRL, maka untuk menghasilkan perilaku petani yang baik dalam pengelolaan HRL, perlu peningkatan intensitas belajar petani HRL melalui penguatan kelembagaan pendukung pembelajaran serta peningkatan kompetensi penyuluh dan pendamping. Model pengembangan pembelajaran petani HRL dalam hal ini lebih difokuskan pada aspek-aspek yang mempengaruhi intensitas belajar, tetapi memiliki indikator-indikator yang dinilai kurang baik oleh petani sehingga perlu ditingkatkan.

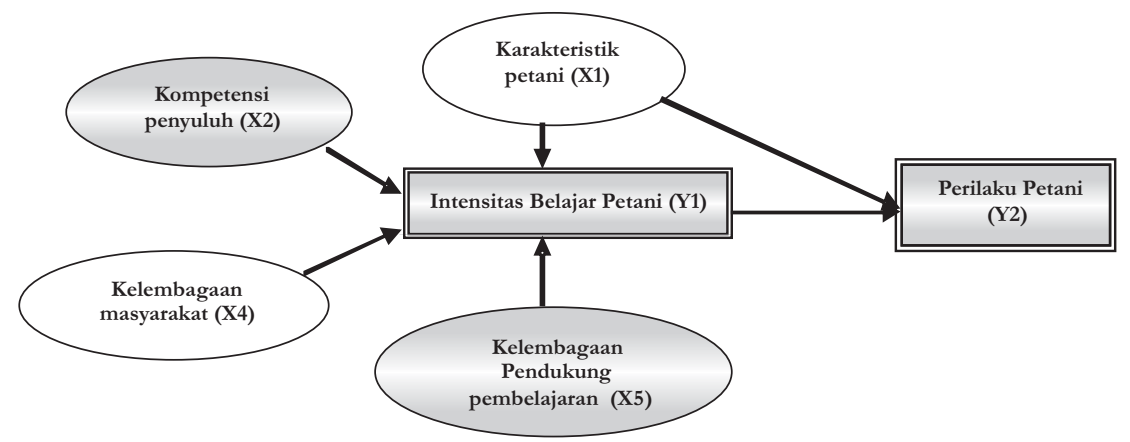

Gambar 3. Model pengembangan pembelajaran petani hutan rakyat lestari

Figure 3. Model of farmer's learning development in implementing sustainable private forest management

Model pengembangan pembelajaran petani HRL perlu dijabarkan ke dalam strategi pengembangan pembelajaran petani HRL yaitu: (1) Strategi penguatan dan pengembangan kelembagaan pendukung pembelajaran yang kolaboratif dan sistemik melalui dukungan kegiatan berkelanjutan dan dukungan personil yang kompeten serta (2) Strategi peningkatan 
kompetensi penyuluh dan pendamping, terutama kemampuan menganalisa permasalahan, meningkatkan kapasitas penyuluh/pendamping, dan meningkatkan wawasan teknis petani dalam pengelolaan HRL.

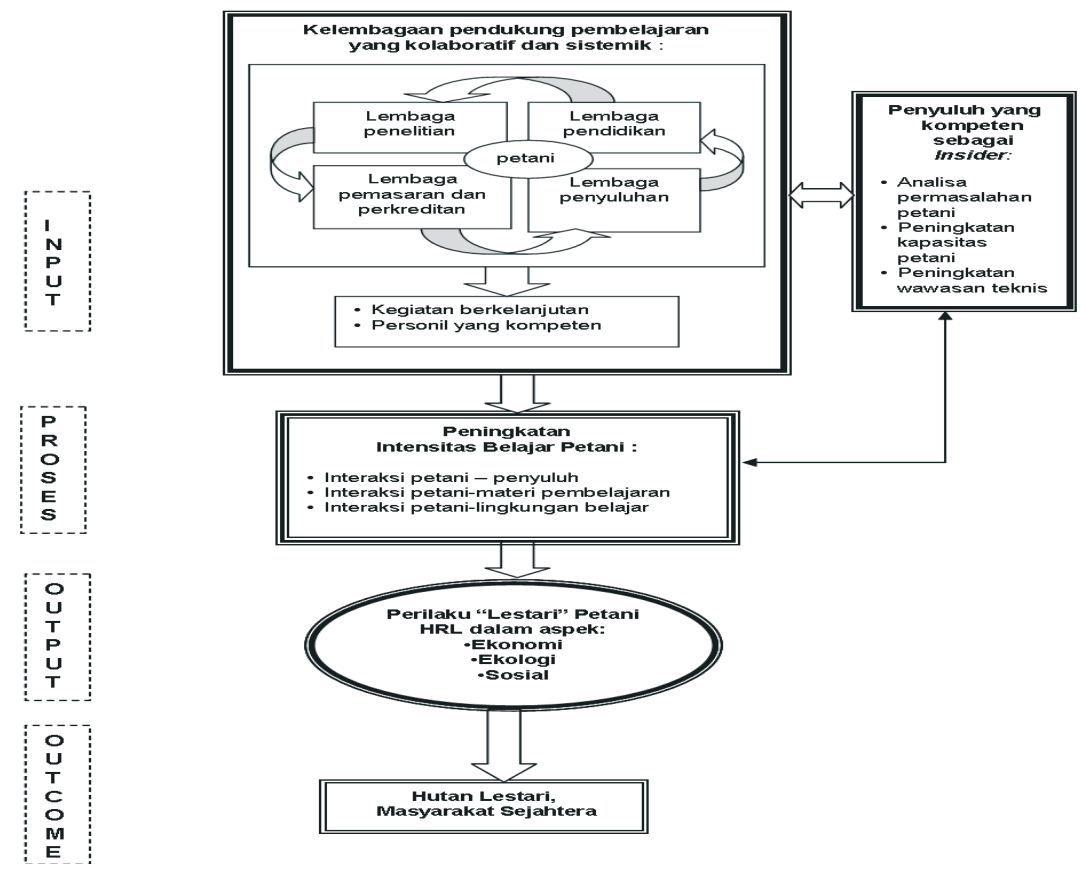

Gambar 4. Strategi pengembangan pembelajaran petani hutan rakyat lestari

Figure 4. Strategy of farmer's learning development in implementing sustainable private forest management

1. Strategi penguatan dan pengembangan kelembagaan pendukung pembelajaran yang kolaboratif dan sistemik:

a. Membentuk kelembagaan pendukung pembelajaran petani HRL yang kolaboratif dan sistemik, dengan melibatkan institusi atau organisasi yang menjalankan fungsi penyuluhan, pendidikan, penelitian dan pemasaran-perkreditan, yang memiliki kesamaan visi, misi dan tujuan dan fokus untuk memberdayakan petani HRL;

b. Menetapkan visi, misi, dan tujuan bersama, dan menjabarkannya dalam program dan kegiatan bersama. Kegiatan difokuskan pada kegiatan pemberdayaan petani yang berkelanjutan, sesuai dengan nilai, kebutuhan riil dan minat petani;

c. Merekrut dan menempatkan personil di lapangan yang memiliki kompetensi dan kepedulian tinggi terhadap pemberdayaan petani.

\section{Strategi peningkatan kompetensi penyuluh dan pendamping:}

a. Penyusunan bersama standar kompetensi penyuluh dan pendamping secara umum, dan secara khusus kompetensi yang berkaitan dengan pengelolaan HRL. Penyusunan standar kompetensi dilakukan dengan melibatkan semua kelembagaan pendukung pembelajaran;

b. Peningkatan kepedulian dan kepekaan penyuluh/pendamping terhadap permasalahan dan kebutuhan riil petani;

Model Pengembangan Pembelajaran Petani dalam Pengelolaan Hutan Rakyat Lestari: ...... (Yumi et al.) 
c. Peningkatan kompetensi melalui pelatihan-pelatihan, yang lebih difokuskan kepada peningkatan kemampuan penyuluh dan pendamping dalam : menganalisa permasalahan petani, meningkatkan kapasitas petani, dan memadukan wawasan teknis HRL dengan pengetahuan lokal petani HRL;

d. Pemberian penghargaan kepada penyuluh dan pendamping yang telah memiliki kompetensi tinggi dan berhasil mendampingi petani HRL sehingga petani mandiri dalam mengelola dan mengembangkan HRL.

\section{KESIMPULAN DAN SARAN}

\section{A. Kesimpulan}

1. Intensitas belajar petani dalam pengelolaan Hutan Rakyat Lestari secara umum tergolong rendah. Rendahnya intensitas belajar petani terutama disebabkan oleh kelembagaan pendukung pembelajaran petani yang tidak berkolaborasi dan bersinergi, kelembagaan masyarakat yang lemah dan kurang dinamis, kompetensi penyuluh/pendamping rendah, serta konsep diri dan motivasi petani pengelola Hutan Rakyat Lestari yang tidak maksimal;

2. Kelembagaan yang berperanan penting dalam pembelajaran petani pengelola Hutan Rakyat Lestari adalah kelembagaan pendukung pembelajaran petani dan kelembagaan masyarakat. Kelembagaan pendukung pembelajaran petani yang terintegrasi dan berkolaborasi secara nyata berperan penting dalam pembelajaran petani rakyat Hutan Rakyat Lestari yang baik. Kelengkapan unsur pemerintah, Perguruan Tinggi, Lembaga Swadaya, dan masyarakat terbukti menghasilkan peningkatan intensitas belajar. Kelengkapan fungsi pendidikan, penelitian, penyuluhan dan pemasaran dalam kelembagaan pendukung berperan dalam peningkatan pembelajaran petani pengelola Hutan Rakyat Lestari. Kelembagaan masyarakat yang berperanan dalam pembelajaran petani Hutan Rakyat Lestari adalah adanya aturan yang konsisten berkaitan pengelolaan Hutan Rakyat Lestari, berfungsinya budaya gotong royong dan etos kerja/giat bekerja, kepercayaan masyarakat terhadap pemimpin, kepemimpinan, dan lembaga informal: arisan, yasinan, dan kelompok tani;

3. Model pengembangan pembelajaran petani pengelola Hutan Rakyat Lestari hasil penelitian ialah peningkatan intensitas belajar petani melalui (1) pengembangan kelembagaan pendukung pembelajaran petani, khususnya melalui peningkatan dukungan kegiatan berkelanjutan dan dukungan personil yang kompeten, serta (2) peningkatan kompetensi penyuluh dan pendamping terutama dalam hal kemampuan menganalisa permasalahan, meningkatkan kapasitas petani, dan meningkatkan wawasan teknis petani dalam pengelolaan Hutan Rakyat Lestari. Model tersebut dapat dijabarkan ke dalam dua strategi yaitu: (1) strategi pengembangan kelembagaan pendukung pembelajaran petani yang kolaboratif dan sistemik, yang difokuskan pada kegiatan bersama yang berkelanjutan dan penempatan personil yang kompeten dalam pendampingan petani pengelola Hutan Rakyat Lestari; dan (2) strategi peningkatan kompetensi penyuluh dan pendamping, yang lebih ditekankan pada peningkatan kemampuan penyuluh dan pendamping dalam menganalisa permasalahan petani, meningkatkan kapasitas petani dan meningkatkan wawasan teknis Hutan Rakyat Lestari yang dipadukan dengan kearifan lokal petani. 


\section{B. Saran}

1. Pengembangan pengelolaan Hutan Rakyat Lestari perlu lebih memperhatikan proses pembelajaran petani. Untuk meningkatkan intensitas belajar petani pengelola Hutan Rakyat Lestari perlu pengembangan kelembagaan pendukung pembelajaran yang kolaboratif dan sistemik, yang melibatkan kaitan sinergi antara institusi atau organisasi yang mempunyai fungsi pelayanan, penelitian, pendidikan dan pemasaran;

2. Peningkatan intensitas belajar petani pengelola Hutan Rakyat Lestari, melalui interaksi dengan penyuluh dan pendamping, materi dan lingkungan belajar perlu dilakukan melalui: (a) peningkatan kompetensi penyuluh dan pendamping melalui pelatihan-pelatihan; (b) pengkajian kebijakan perekrutan, serta penempatan penyuluh dan pendamping; (c) peningkatan kapasitas petani dalam mengakses materi pembelajaran secara mandiri; (d) peningkatan kapasitas petani dalam menjalin kemitraan dengan berbagai pihak berkaitan pengelolaan Hutan Rakyat Lestari;

3. Peningkatan peranan kelembagaan masyarakat dalam pembelajaran petani perlu dilakukan melalui penguatan lembaga-lembaga informal seperti arisan, kelompok pengajian, menjadi wadah pembelajaran petani, serta peningkatan kapasitas petani dalam manajemen kelompok atau organisasi.

\section{DAFTAR PUSTAKA}

Chamala S, Shingi PM. 1997. Establishing and Strengthening Farmer Organizations. Di dalam: Improving Agricultural Extension. Rome: Food and Agriculture Organization of the United Nations.

Chambers R. 1993. Challenging The Professions. Frontiers for Rural Development. London: Intermediate Technologi Publications Ltd.

Darusman. 1995. Hutan Rakyat: Pengembangan Strategis Kehutanan dalam Pembenahan Kehutanan Indonesia, Dokumentasi Kronologi Tulisan 1986-2002. Bogor: Laboratorium Politik Ekonomi dan Sosial dan Yayasan Dani Hanifah.

Djogo T. 2005. Kepemimpinan lingkungan: Kelembagaan, kekuasaan dan konstituen dalam urgensi kepemimpinan dalam pembangunan berkelanjutan. Di dalam: Indonesian Journal for Sustainable Future 1:1-28.

Franz NK. 2003. Transformative learning in extension staff partnerships: Facilitating personal, joint, and organizational change. Di dalam Journal of Extension 39. http://joe.org/joe/2003april/a1.shtml [6 agustus 2010]

Klausmeier HJ, Goodwin W. 1971. Learning and Human Abilites: Educational Pschology. Fourth Ed. New York: Harper \& Row Publisher.

Kraenzel DG. 2001. Building working relationships in agricultural marketing. Di dalam Journal of Extension 39. http://joe.org/joe/2001 february/ttl.html [6 agustus 2010]

Pretty JN. 1995. Regenerating agriculture: Policies and practise for sustainability and selfreliance. London: Earthscan Publications Ltd.

Model Pengembangan Pembelajaran Petani dalam Pengelolaan Hutan Rakyat Lestari: ...... (Yumi et al.) 
Seng OT et.al. 2001. Educational Psychology. Singapore: Seng Lee Press.

Soemanto WS. 2006. Psikologi Pendidikan. Jakarta: Rineka Cipta.

Sudjana SHD. 2000. Strategi Pembelajaran. Bandung: Falah Production.

Suhardjito D dkk. 2000. Karakteristik Pengelolaan Hutan Berbasiskan Masyarakat. Yogyakarta: Studi Kolaboratif FKKM.

Suryabrata S. 2006. Psikologi Pendidikan. Jakarta: Rajawali Pr. 